\title{
Fawn gets Orchid \\ or either Fawn gets Orchid or i do
}

\author{
Trish Salah
}

Le texte de Salah nous trimballe à travers différentes rencontres entre Fawn, Orchid et la narratrice. Ces rencontres, qu'elles soient de cet univers ou d'un autre, sont des suites sensuelles et sexuelles où se mêlent le désir de posséder, la tendre violence, les baisers, les blessures..... où la sexualité et aussi le sexe des personnages et de la narratrice (narrateur?) sont confondus de façon à créer un univers sexuel dépourou de limites. Un fantasme où être vivant ou mort, être "elle" ou "il," être personnage ou narratrice ne limite pas l'expérience.

Fawn was into leaning into gas lamps that august, her head full of airy filth and hung with nuclear fever, long and silver laced, breathless, she stank of fruit candy kisses, her pussy tingled at you, and meat packing, you put it into language. you were a bear with callused paws rubbed raw off cobblestones and wrapped them so craftily round her tits she didn't even notice, just fixed her lips pure and studied in the rearview mirror.

you thought she looked familiar.

once out of that heat Fawn was a girl, sure. cool and composed for all the feral animal language wrapped around her lupine supine bovine feline canine ursine lines and signs composed so exactly at the caress of skins no lone stranger friend could tell her for what she was, she was not.

Fawn bared girlskin that night, leopard print hip-huggers, and his hooves were cloven, begging eyes and big jugs pointed, navigating the steel pole limo. shimmied round the hot tub faux leather fields forever and your gritty ingratiating smile. closed in that exposure he felt about him only jagged steel, teeth spring-loaded, couldn't tell if she was having fun. under the 
leopard print the deer girl the shattered bones the memory lapses the straight A student boy next door in his big sister's underwear.

in those days he was writing poems. in a poem he once was falling from a hand giving love to strangers. he ran into you, Orchid, and that prelude was never published. you happened to be his absolute, not incidentally.

with your hands up her asshole for a million billion years she was foundering without a thing beneath her feet. you brought out the her in him. until you dumped him in the gutter. until she found you again.

Fawn was naughty that night, not nice. she didn't know what to do with you but she thought it should hurt. still she was not so proud as to deny herself the fantasy of having you again. let's just say, in her kissing and killing you oh so swollen and purple, she felt a definite affection. "let it take a long time," she thought. bored her plastered-on dagger nails as black as black as deep into your thighs as they would go. and left innocent for the moment cherry red lips plumped around incisors the size of her cat $o^{\prime}$ nine tails swishing fondly between her legs.

\section{II}

and now Fawn's feeling smeared by you, Orchid (by Orchid's death). your difference marked in real and what real is, is the thing she can count on, next to her, Orchid's skin. your skin is cold skin, Orchid. this is annexed and the one is yoked to the dreaming other, as if difference were the first thing before kisses or bruises or as if those were not residing in difference and Fawn's feeling bruised which also darkens with kisses pink to plum and though it's been sexy before it's been real, this time it's different and you are no longer a lover, Orchid. you broke her right off, here at knees and arms, and since ashes ashes all fall down she's determined you will too.

and she's feeling darker because she got you and you deserved it (even if you didn't deserve it) and you're lost to her, here. this becomes the most hurtling fast difference she cannot catch up to, get next to 
in another universe things worked out differently.

there Fawn also became an assassin, which is also sex training, but she took up dark painting metaphors to soothe herself in her mornings. she edged the names of Dutch masters (Bosch and Bruegel and van Eyck) into margins of countless Persian carpets and felt a little better for the open thanatos in her eros, her little bit of milk and sugar.

and so the night she finds Orchid, and straightens her out (dead), it's not purely a righteous thing. Fawn is envious in all her black leather, watching our scene. repeats memory snapshots like whip cracks on Orchid's thighs and still in her skin, fast welted skin clings to manacles - what kind of crack tastes like her mouth, hungry tastes as if my hand could fit all the way in? ecstatic (ex-static), we have no bones limits and skin carries through skin, steaming. she fears this endless is endless

but she's turned on too and in that universe she can go with it. i can't say why it turned out different (in our universe). we should have gone with her to the fine arts museum more often.

it's just we get lost in just shards. Orchid attends me still as you used to, deftly springs into her chains ready for my use - but that is so mechanical you might say to her - what of your difference? your abandonment?

poor puss, weeping for days swinging in the breeze when your faults are not reprimanded and with that she and i converge, old girlfriends admonishing a testy novice.

you're laid out flat on the glass peering through the restaurant skylight where i drip white wine on his tits and butter fresh from the creamery melts at the press of her thighs jiggling and curved as a spoon turning in pussy. idylls -

*

because we dream this later it is fantasy an imaginary other 


\section{Fawn gets Orchid $\cdot 95$}

dimension

and not real

Orchid is dead in the alley

because we dream this later -

(it is fantasy, not real)

Fawn has a hungry mouth here too, taut and thinned and (this is a nexus in this or any dimension) she has a fantasy she doesn't know what to think about: that she is a boy, tough and swaggering, in the navy with her own skinflower, a pretty past now her future, a whore who shackles her self

to bed each night hoping for violence for something to dig into something like you Orchid, only not dead walking around, a girl about town Fawn watches you sometimes 
